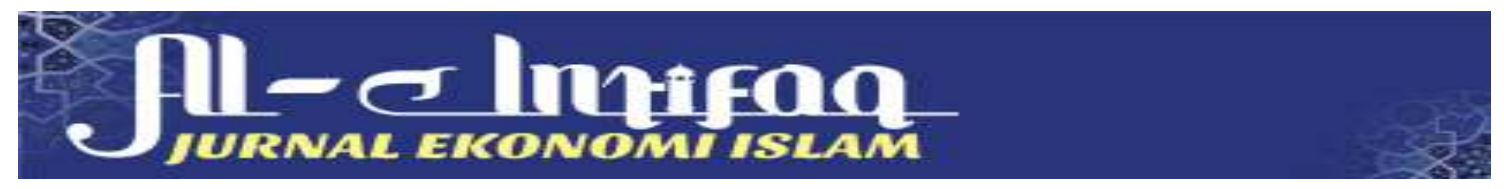

\title{
Pengaruh Kurs Dolar As Dan Inflasi Terhadap Dana Pihak Ketiga (DPK) Pada Bank Nagari Syariah Cabang Batusangkar
}

\author{
Emiliyani Wahyuni S1, Yeni Melia ${ }^{2}$, Meria Ulfa ${ }^{3}$ \\ Fakultas Ekonomi dan Bisnis Islam, Institut Agama Islam Negri \\ elmiliyaniwahyuni@iainbatusangkar.ac.id ${ }^{1}{ }^{1}$ yenimelia@iainbatusangkar.ac.id ${ }^{2}$
}

\begin{abstract}
Absrtact: This study aims to analyze and determine the effect of the US Dollar Exchange Rate and Inflation on Third Party Funds (TPF) at Bank Nagari Syariah Batusangkar Branch for the period 2013-2018. The type of research used in this research is field research with quantitative research methods using a descriptive approach, and using eviews analysis tools with multiple regression and using the Ordinary Least Square (OLS) estimation method. The results of this study indicate that the US Dollar exchange rate variable with a coefficient value (8.141176), the probability value (o.o332) has a positive and significant effect on Third Party Funds (TPF), the inflation variable has a negative and insignificant effect on Third Party Funds (TPF) with a coefficient value ( -0.697542$)$ probability value (o.1019) while the variable US dollar exchange rate and inflation together have a positive and significant effect on third party funds using the Ordinary Least Square (OLS) method, the F-statistic value is 31.98483 with a probability of 0.009481.
\end{abstract}

Keywords: US Dollar Exchange Rate, Inflation, Third Party Funds (TPF)

Abstrak: Penelitian ini bertujuan untuk menganalisis dan mengetahui pengaruh Kurs Dolar AS dan Inflasi terhadap Dana Pihak Ketiga (DPK) pada Bank Nagari Syariah Cabang Batusangkar periode tahun 2013-2018. Jenis penelitian yang digunakan dalam penelitian ini adalah field reseach dengan metode penelitian kuantitatif menggunakan pendekatan deskriptif, dan menggunakan alat analisis eviews dengan regresi berganda serta menggunakan metode estimasi Ordinary Least Square (OLS). Hasil penelitian ini menunjukan bahwa variabel Kurs Dolar AS dengan nilai coefficient (8.141176) nilai pobability (0.0332) berpengaruh positif dan signifikan terhadap Dana Pihak Ketiga (DPK), variabel inflasi berpengaruh negatif dan tidak signifkan terhadap Dana Pihak Ketiga (DPK) dengan nilai coefficient (-o.697542) nilai probability (0.1019) sedangkan variabel kurs dolar AS dan Inflasi secara bersama-sama memiliki pengaruh yang positif dan signifikan terhadap dana pihak ketiga dengan metode Ordinary Least Square (OLS) diperoleh nilai $F$-statistic sebesar 31.98483 dengan probability 0.009481 .

Kata Kunci : Kurs Dolar AS, Inflasi, Dana Pihak Ketiga (DPK)

\section{PENDAHULUAN}

Kehidupan perekonomian di Indonesia tidak pernah terlepas dari dunia perbankan. Perbankan merupakan salah satu tulang punggung perekonomian yang memiliki fungsi sebagai pembangunan nasional serta sebagai perantara bagi sektor yang mengalami kesulitan uang dengan sektor yang kelebihan uang (defisit ke surplus).

Ada dua macam produk yang bisa digunakan oleh masyarakat terhadap bank yang pertama produk penghimpunan dana dan yang kedua produk penyaluran dana.

37 Pengaruh Kurs Dolar As Dan Inflasi Terhadap Dana Pihak Ketiga (DPK) Pada Bank Nagari Syariah Cabang Batusangkar 
Kedua produk tersebut sangat diperlukan oleh bank syariah untuk berkembang. Pentingnya sumber dana dari masyarakat luas merupakan sumber dana yang paling utama bagi bank. Dana yang berhasil dihimpun akan menjadi beban apabila dibiarkan begitu saja tanpa ada alokasi untuk tujuan yang produktif. Dalam penghimpunan dana bank syariah melakukan mobilisasi dan investasi tabungan yang adil. Sumber dana bank berasal dari modal disetor dan hasil mobilisasi kegiatan penghimpunan dana melalui rekenig giro, rekening tabungan dan rekening deposito atau disebut juga dengan Dana Pihak Ketiga (DPK).

Berdasarkan hasil laporan keuangan PT. Bank Nagari Syariah Cabang Batusangkar periode 2013-2018 tingkat inflasi cenderung naik-turun. Tingkat inflasi mengalami kenaikan, masing-masing sebesar $8.38 \%$ dan $8.36 \%$. Apabila terjadi inflasi maka akan membuat kondisi makro ekonomi suatu negara berada dalam ketidakpastian yang mengakibatkan masyarakat cenderung menggunakan dananya untuk konsumsi, sehingga masyarakat tidak memiliki kelebihan dana untuk disimpan dalam bentuk tabungan dan juga sangat berpengaruh terhadap jumlah Dana Pihak Ketiga (DPK). Namun begitu juga dengan variabel kurs Dolar Amerika Serikat (Dolar AS) juga mengalami kenaikan dari tahun 2013 s.d 2015 namun realitanya berbanding terbalik terhadap jumlah Dana Pihak Ketiga (DPK) periode 2013-2018 justru mengalami kenaikan.

Bebrapa penelitian yang dilakukan sebelumnya diantaranya tentang analisis pengaruh PDB, inlasi, tingkat bunga dan nilai tukar teradap dana pihak ketiga bank umum syariah di indonesi oleh Abida Mutaqiena dengan hasil penelitian menunjukan bahwa PDB, Inflasi, suku bunga Deposito bukan bank umum, nilai rupiah secara simultan (Uji F) maupun Parsial (Uji T) berpengaruh dan signifikan terhadap Dana Pihak Ketiga pada Bank Umum Syariah di Indonesia (2008-2012) persamaan dengan penelitian ini adalah variabel $Y=$ dana pihak ketiga (DPK) $X=$ Kurs dolar dan inflasi sedangkan perbedaannya adalah dari tempat penelitian, serta cakupan penelitian Abida mutaqiena mengenai bank syariah di seluruh Indonesia sedangkan peneliti hanya meneliti satu bank saja.

Penelitian ini bertujuan untuk mengetahui seberapa besar pengaruh variabel kurs Dolar Amerika Serikat, inflasi, dan pengaruhnya secara bersama-sama terhadap Dana Pihak Ketiga di Bank Nagari Syariah Batusangkar.

\section{KAJIAN TEORI}

Menurut Gampito Ekonomi islam adalah suatu ilmu pengetahuan yang berupaya untuk memandang, meninjau, meneliti dan akhirnya menyelesaikan permasalahan-permasalahan ekonomi dengan cara-cara yang islami dengan mendasarkan segala aspek ontologi, epistimologi dan aksiologinya kepada agama islam. (Gampito, 2013: 17)

Menurut Muhammad, bank syariah adalah suatu bank yang beroperasi dengan tidak mengandalkan pada bunga. Produk dan operasional perbankan syariah dikembangkan berdasarkan pada AlQuran dan Hadis Nabi Muhammad SAW. Atau dengan kata lain, bank syariah merupakan lembaga keuangan dengan usaha utamanya memberikan pembiayaan dan jasa-jasa lain yang operasionalnya disesuaikan dengan prinsip-prinsip Islam (Muhammad,2005:13).

Sumber dana bank syariah terdiri dari(Arifin,2006:47-50)

1. Modal inti

2. Kuasi ekuitas

3. Dana titipan 
Dana pihak ketiga atau dana masyarakat adalah dana-dana yang berasal dari masyarakat, baik secara perorangan maupun badan usaha yang di dapatkan oleh bank dengan menggunakan berbagai istrumen produk simpanan yang dimiliki bank. Dana masyarakat merupakan dana terbesar yang dimiliki bank. Ini sesuai dengan fungsi bank sebagai penghimpun dana dari pihak-pihak yang kelebihan dana dalam masyarakat. Dana masyarakat itu dihimpun bank dengan produk-produk simpanan seperti: giro dalam istilah bank syariah (demand deposit) deposito (time deposit), dan tabungan saving. (Iska, 2012:32)

Jenis dana pihak ketiga:

1. Tabungan

2. Deposito

3. Giro

Faktor-faktor yang mempengaruhi penghimpunan DPK Perbankan Syariah:

1. PDRB terhadap DPK

2. Suku bunga terhadap DPK

3. Depedency Ratio terhadap DPK

4. Kurs Terhadap DPK

5. Inflasi terhadap DPK

Nilai tukar suatu mata uang atau kurs adalah nilai tukar mata uang suatu negara terhadap negara asing lainya (Thobarry, 2009). Nilai tukar biasanya berubah-ubah, perubahan kurs dapat berupa depresiasi dan apresiasi. Depresiasi mata uang rupiah terhadap dollar AS artinya suatu penurunan harga Dolar Amerika (dolar AS) terhadap rupiah. Sedangkan apresiasi rupiah terhadap Dolar Amerika (dolar AS) adalah kenaikan rupiah terhadap USD di kutip dalam buku Anwary, 2011:17 terdapat dalam (Muchlas, 2015: 76)

Inflasi adalah proses kenaikan harga secara terus-menerus. Sedangkan kebalikan dari inflasi adalah deflasi yaitu penurunan harga secara terus-menerus, akibatnya daya beli masyarakat bertambah besar, sehingga pada tahap awal bearang-barang menjadi langka, akan tetapi pada tahap berikutnya jumlah barang akan semakin banyak karena semangkin berkurangnya daya beli masyarakat. (Putong, 2010:397)

Dapat di inflasi jika ada tiga faktor yaitu :

1. Kenaikan harga

2. Sifatnya umum

3. Berlangsung secara terus menerus

Ada beberapa faktor masalah sosial yang muncul dari inflasi yaitu :

1. Menurunya tingkat kesejahtraan masyarakat

2. Memburuknya distribusi pendapatan

3. Terganggunya stabilitas ekonomi.

Dalam sistem ekonomi Islam inflasi bukan merupakan suatu masalah utama ekonomi secara agregat, karena mata uangnya stabil dengan digunakannya mata uang dinar dan dirham. Penurunan nilai masih mungkin terjadi, yaitu ketika nilai emas yang menopang nilai nominal dinar itu mengalami penurunan, diantaranya akibat ditemukannya emas dalam jumlah yang besar, tapi keadaan ini kecil sekali kemungkinannya. Menurut para ekonom Islam, inflasi berakibat sangat buruk bagi perekonomian karena: Menimbulkan gangguan terhadap fungsi uang, terutama 
terhadap fungsi tabungan, fungsi dari pembayaran di muka, dan fungsi dari unit perhitungan. Melemahkan semangat menabung dan sikap terhadap menabung dari masyarakat. Meningkatkan kecenderungan untuk berbelanja terutama untuk nonprimer dan barang- barang mewah. Mengarahkan investasi pada hal-hal yang nonproduktif, yaitu penumpukkan kekayaan seperti : tanah, bangunan, logam mulia, mata uang asing dengan mengorbankan investasi kearah produktif seperti : pertanian, peternakan, pertambangan, industrial, perdagangan, transportasi, jasa dan lainnya (Idris, 2016: 41)

1. Produk Dana Pihak Ketiga Bank Nagari Syariah
a. Produk Dana
b. Giro Syariah Wadiah
c. Tabungan Sikoci Syariah Mudharabah
d. Tabungan Tahari Syariah Mudharabah
e. Deposito Mudharabah

2. Produk Pembiayaan
a. Pembiayaan Murabahah Modal Kerja
b. Pembiayaan Murabahah Investasi
c. Pembiayaan Murabahah Plus
d. Pembiayaan Murabahah Pegawai Intern
e. Pembiayaan Modal Kerja Kontraktor (PMKK)
f. Pembiayaan Musyarakah Mutanaqishah

\section{METODE PENELITIAN}

\section{Jenis Penelitian}

Jenis penelitian ini field research dengan pendekatan kuantitatif. Penelitian kuantitatif adalah suatu proses menemukan pengetahuan menggunakan data berupa angka sebagai alat untuk menemukan keterangan yang ingin kita ketahui. Penelitian deskriptif merupakan penelitian yang berusaha mendeskripsikan suatu peristiwa yang menjadi pusat perhatian untuk digambarkan sebagaimana adanya. Pada penelitian ini penulis ingin melihat seberapa besar pengaruh kurs Dolar Amerika (Dolar AS) dan inflasi terhadap dana pihak ketiga di Bank Nagari Syariah Cabang Batusangkar tahun 2013-2018.

\section{Teknik analisis data}

Teknik analisa data adalah interprestasi terhadap data yang diperoleh secara sistematis dan teoritis sehingga menghasilkan kesimpulan yang tepat dan dapat dipertanggung jawabkan secara ilmiah. Untuk mengolah data dibantu dengan aplikasi komputer Microsoft Exel 2010 dan Eviews 8.0. Dalam analisis data kuantitatif, alat analisis yang digunakan adalah sebagai berikut :

1. Uji asumsi klasik

\section{Uji normalitas}

Uji normalitas bertujuan untuk mengetahui data dalam variabel yang akan digunakan dalam penelitian apakah suatu variabel normal atau tidak, data yang baik dan layak digunakan dalam penelitian adalah data yang memiliki distribusi normal. Pengujian terhadap residual terdistribusi normal atau tidak dapat menggunakan jarque bera test (JB test). (Iqbal, 2015: 18) 
Langkah-langkah pengujian normalitas data sebagai berikut:

hipotesis

bila probabilitas jarque-Bera $>0.05=$ signifikan

bila probabilitas jarque-Bera $<0.05=$ tidak signifikan

\section{Uji multikolenieritas}

Uji multikolenieritas diperlukan untuk mengetahui ada tidaknya variabel independen yang memiliki kemiripan antar variabel independen dalam suatu mode. (Wiranta, 2015: 185)

\section{Uji autokorelasi}

Uji autokorelasi adalah suatu keadaan dimana telah terjadi kolerasi antara residual tahun ini dengan tingkat kesalahan tahun sebelumnya.

Untuk melihat ada tidaknya penyakit autokorelasi dapat juga digunakan uji Langrange multiplier (LM Test) atau yang disebut uji Breusch Godfrey dengan membandingkan nilai probabilitas R-squared dengan $a=5 \%$ (0.05).(Iqbal, 2015:15)

Langkah-langkah pengujianya sebagai berikut :

Hipotesis :

Bila probabilitas $\mathrm{Obs}^{*} \mathrm{R}_{2}>0.05=$ Signifikan

Bila probabilitas Obs* $\mathrm{R}_{2}<0.05=$ Tidak Signifikan

Apabila probabilitas $\mathrm{Obs}^{*} \mathrm{R}_{2}$ lebih besar dari 0.05 maka model tersebut tidak terdapat autokorelasi.

\section{Uji Heteroskedastisitas}

Heteroskedastisitas adalah varian residual yang tidak sama pada semua pengamatan didalam model regresi. Regresi yang baik seharusya tidak terjadi heteroskedastisitas pendeteksian heteroskedastisitas yang penulis gunakan melalui uji Glejser keputusan terjadi atau tidaknya heteroskedastisitas pada model regresi linear adalah dengan melihat Nilai Prob. F-statistic (F hitung). Apabila Nilai Prob. F hitung lebih besar dari tingkat a $=5 \%(0.05)$ maka $\mathrm{H}_{0}$ diterima yang artinya tidak terjadi heteroskedastisitas, sedangkan apabila Nilai Prob. F hitung lebih kecil dari tingkat $\mathrm{a}=5 \%(0.05)$ maka $\mathrm{H}_{0}$ ditolak yang artinya terjadi heteroskedastisitas. (Iqbal, 2015: 19)

2. Pengujian Hipotesis

Regresi linier berganda

Dalam penelitian ini digunakan motode kuantitatif dengan alat analisis regresi linier berganda. Regresi ini digunakan ketika peneliti ingin memprediksi variabel-variabel tertentu dengan dengan menggunakan variabel lain (Darmawan,2014:179). Dalam analisis regresi linier berganda untuk menguji hipotesis yang telah diajukan dan untuk mengolah dan membahas data yag di peroleh, dimana dalam analisis linier regresi tersebut akan menguji jumlah dana pihak ketiga (DPK), kurs Dolar Amerika (Dolar AS) dan inflasi di Bank Nagari Syariah Batusangkar.

Analisis regresi linier berganda digunakan oleh peneliti, peneiti bermaksud untuk meramalkan bagaimana keadaan (naik turunya) variabel dependen (kriterium), bila dua atau lebih variabel independen sebagai faktor 
predictor dimanipulasi di naik turunkan nilainya, (Wiranta, 2015:186). Maka dalam penelitian ini yang menjadi variabel independen $\left(X_{1}\right)$ adalah Kurs Dolar Amerika (Dolar AS) dan $\left(\mathrm{X}_{2}\right)$ adalah Inflasi, dan variabel dependen $(Y)$ adalah Dana Pihak Ketiga .

Adapun rumus yang dipakai yang di sesuaikan dengan jumlah variabel yang di teliti adalah :

$$
\begin{aligned}
& \mathrm{Y}=\mathrm{a}+\mathrm{b}_{1} \mathrm{X}_{1}+\mathrm{b}_{2} \mathrm{X}_{2}+\mathrm{e} \\
& \mathrm{Y}=\text { Dana pihak ketiga } \\
& \mathrm{a} \quad \text { Konstanta } \\
& \mathrm{b}_{1} \quad=\text { Koefisien regresi untuk } \mathrm{X}_{1} \\
& \mathrm{~b}_{2}=\text { Koefisien regresi untuk } \mathrm{X}_{2} \\
& \mathrm{X}_{1}=\text { Kurs dollar } \\
& \mathrm{X}_{2}=\text { Inflasi } \\
& \mathrm{e} \quad=\text { erorr }
\end{aligned}
$$

Setelah data di log maka persamaan regresi linier berganda yang digunakan dalam penelitian ini menjadi

$$
\begin{aligned}
& \operatorname{Ln} \breve{Y}=\beta_{0}+\beta_{1} \operatorname{LnX}_{1}+\beta_{2} \operatorname{Ln} X_{2}+e \\
& \text { Di mana : } \\
& \text { LnY }=\text { Logaritma natural Dana Pihak Ketiga (DPK) } \\
& \beta_{0} \quad=\text { Konstanta } \\
& \beta_{1} \quad=\text { Koefisien Regresi Dari Variabel Independen Kurs Dollar } \\
& \beta_{2} \quad=\text { Koefisien Regresi Dari Variabel Independen Inflasi } \\
& \text { Ln } X_{1}=\text { Logaritma Natural Kurs Dollar } \\
& \text { Ln } X_{2}=\text { Logaritma Natural Inflasi } \\
& \mathrm{e} \quad=\text { Error }
\end{aligned}
$$

\section{Uji T}

Uji $\mathrm{T}$ dilakukan untuk menguji apakah secara terpisah variabel independen mampu menjelaskan variabel dependen secara baik. Dalam melakukan estimasi data maka digunakan tingkat toleransi kesalahan sebesar $5 \%$ atau sebesar 0.05 , dimana :

1. Apabila nilai probbability $\mathrm{T}$ hitung lebih $<$ dari a $=0.05$ maka $\mathrm{H}_{0}$ ditolak $\mathrm{H}_{\mathrm{a}}$ diterima, artinya variabel bebas berpengaruh signifikan terhadap variabel terikat. Disini maksudnya adalah :

a. Kurs Dolar Amerika (Dolar AS) berpengaruh signifikan terhadap Dana Pihak Ketiga (DPK) tahun 2013-2018

b. Inflasi berpengaruh signifikan terhadap Dana Pihak Ketiga (DPK) tahun 2013-20178

c. Apabila nilai probbability $\mathrm{T}$ hitung lebih $>$ dari $\mathrm{a}=0.05$ maka $\mathrm{H}_{0}$ diterima $\mathrm{H}_{\mathrm{a}}$ ditolak, artinya variabel bebas tidak berpengaruh signifikan terhadap variabel terikat. Kurs Dolar Amerika (Dolar AS) tidak berpengaruh signifikan terhadap Dana Pihak Ketiga (DPK) tahun 2013-2018

d. Inflasi berpengaruh signifikan terhadap Dana Pihak Ketiga (DPK) tahun 2013-2018 (Iqbal, 2014:25)

Uji F Tes 
Uji F dilakukan untuk mengetahui apakah antara variabel bebas (Kurs Dolar Amerika (Dolar AS) dan inflasi) secara bersama-sama memiliki pengaruh yang signifikan terhadap variabel yang tidak bebas (Dana Pihak Ketiga (DPK)). Dalam melakukan estimasi data maka digunakan tingkat toleransi kesalahan sebesar $5 \%$ atau sebesar 0.05 dimana :

1. Apabila nilai probability $\mathrm{F}$ hitung lebih $<$ dari $\mathrm{a}=0.05$, maka hal ini berarti variabel bebas mampu menjelaskan variabel terikat secara bersama-sama, dalam penelitian ini berarti : Kurs Dolar Amerika (Dolar AS) dan inflasi berpengaruh signifikan terhadap Dana Pihak Ketiga (DPK) dengan menggunkan uji $\mathrm{F}$

2. Sebaliknya Apabila nilai probability $\mathrm{F}$ hitung lebih $>$ dari $\mathrm{a}=0.05$, maka hal ini berarti variabel bebas secara bersama-sama, tidak mampu menjelaskan variabel terikat, dalam penelitian ini berarti : Kurs Dolar Amerika (Dolar AS) dan inflasi tidak berpengaruh signifikan terhadap Dana Pihak Ketiga (DPK) dengan menggunkan uji F. (Iqbal, 2014:24)

\section{Uji Koefisien Determinasi}

Uji koefisien determinasi digunakan untuk mengetahui besarnya persentase variabel terikat yang dapat diprediksi dengan menggunakan variabel bebas. Koefisien determinasi digunakan untuk menghitung besarnya peranan atau pengaruh variabel terikat.

\section{HASIL DAN PEMBAHASAN}

Hasil Penelitian

1. Perkembangan Kurs Dolar Amerika (Dolar AS)

Tabel 1

Data Kurs Dolar Amerika Periode 2013-2018 Dalam Bentuk Rupiah (Rp)

\begin{tabular}{|l|l|l|l|l|l|l|}
\hline Bulan & 2013 & 2014 & 2015 & 2016 & 2017 & 2018 \\
\hline Januari & 9,698 & 12,226 & 12,625 & 13,846 & 13,343 & 13,398 \\
\hline Februari & 9,667 & 11,634 & 12,863 & 13,395 & 13,347 & 13,707 \\
\hline Maret & 9,719 & 11,404 & 13,084 & 13,276 & 13,321 & 13,756 \\
\hline April & 9,722 & 11,532 & 12,973 & 13,204 & 13,327 & 13,877 \\
\hline Mei & 9,802 & 11,611 & 13,211 & 13,615 & 13,321 & 13,951 \\
\hline Juni & 9,929 & 11,969 & 13,332 & 13,180 & 13,319 & 14,404 \\
\hline Juli & 10,278 & 11,591 & 13,481 & 13,094 & 13,323 & 14,413 \\
\hline Agustus & 10,924 & 11,717 & 14,027 & 13,300 & 13,351 & 14,711 \\
\hline September & 11,613 & 12,212 & 14,657 & 12,998 & 13,492 & 14,929 \\
\hline Oktober & 11,235 & 12,082 & 13,639 & 12,051 & 13,572 & 15,227 \\
\hline November & 11,977 & 12,196 & 13,840 & 13,563 & 13,514 & 14,399 \\
\hline Desember & 12,189 & 12,440 & 12,440 & 13,436 & 13,548 & 14,481 \\
\hline
\end{tabular}

Sumber: www.bi.go.id

Tabel diatas menunjukkan pergerakan Nilai Tukar Rupiah terhadap Dolar Amerika (Kurs Rupiah/US Dollar). Berdasarkan tabel, besarnya nilai Kurs dari tahun ke tahun selalu mengalami kenaikan dan penurunan yang tidak stabil. Pergerakan Kurs mengalami fluktuasi di setiap tahunnya, dapat diketahui bahwa kurs Dolar Amerika tertinggi terjadi pada bulan Oktober 2018 sebesar Rp 15.227,

Pengaruh Kurs Dolar As Dan Inflasi Terhadap Dana Pihak Ketiga (DPK) Pada Bank Nagari Syariah Cabang Batusangkar 
dan kurs Dolar terendah pada bulan Februari 2013 sebesar Rp. 9.667. Secara keseluruhan kurs Dolar Amerika mengalami fluktuatif setiap tahunya, yang mana pada Desember 2013 sebesar Rp 12.189 menjadi Rp 14.481 pada Desember 2018.

\section{Perkembangan Inflasi di Indonesia}

\section{Tabel 2}

Data Inflasi Periode 2013-2018

Dalam Bentuk Pesentase (\%)

\begin{tabular}{|l|l|l|l|l|l|l|}
\hline Bulan & 2013 & 2014 & 2015 & 2016 & 2017 & 2018 \\
\hline Januari & 4,57 & 8,22 & 6,96 & 4,14 & 3,49 & 3,25 \\
\hline Februari & 5,31 & 7,75 & 6,29 & 4,42 & 3,83 & 3,18 \\
\hline Maret & 5,90 & 7,32 & 6,38 & 4,45 & 3,61 & 3,40 \\
\hline April & 5,57 & 7,25 & 6,79 & 3,60 & 4,17 & 3,41 \\
\hline Mei & 5,47 & 7,72 & 7,15 & 3,33 & 4,33 & 3,23 \\
\hline Juni & 5,90 & 6,70 & 7,26 & 3,45 & 4,37 & 3,12 \\
\hline Juli & 861 & 4,53 & 7,26 & 3,21 & 3,88 & 3,18 \\
\hline Agustus & 8,79 & 3,99 & 7,18 & 2,79 & 3,82 & 3,20 \\
\hline September & 8,40 & 8,53 & 6,83 & 3,07 & 3,72 & 3,88 \\
\hline Oktober & 8,32 & 4,83 & 6,25 & 3,31 & 3,58 & 3,16 \\
\hline November & 8,37 & 6,23 & 4,89 & 3,58 & 3,30 & 3,23 \\
\hline Desember & 8,38 & 8,23 & 3,35 & 3,02 & 3,61 & 3,13 \\
\hline
\end{tabular}

Sumber : www.bi.go.id

Berdasarkan tabel diatas dapat diketahui inflasi tertinggi terjadi pada bulan agustus tahun 2013 sebesar $8.38 \%$ dan tingkat inflasi terendah terjadi pada bulan agustus tahun 2016 sebesar 2,79\% secara keseluruhan dari periode 2013 sampai dengan 2018 perkembangan inflasi fluktuatif karena selalu mengalami kenaikan dan penurunan yang selalu berubah setiap bulanya. Tahun 2013-2014 tingkat inflasi masing-masing 8,38\% dan 8,36\%, beberapa hal menjadi penyebabnya adalah karena kenaikan barang impor, kenaikan tingkat upah tenaga kerja yang tidak diimbangi peningkatan produktifitasnya, kenaikan harga barang komoditas beras dan kanaikan BBM.

\section{Perkembangan bank syariah}

Kini perbankan syariah telah mengalami perkembangan, pertumbuhan bank syariah saat ini menunjukan besarnya permintaan masyarakat terhadap jasa perbankan syariah. Hal ini tercermin dari pertumbuhan jumlah bank yang signifikan dari jaringan kantor maupun kinerja keuangan perbankan syariah selama tahun 2011, jumlah bank yang melaksanakan kegitan usaha berdasarkan prinsip syariah mengalami peningkatan.

Kondisi perbankan syariah pada tahun-tahun selanjutnya diperkirakan akan terus membaik. Ini terbukti masih tingginya minat mayarakat terhadap perbankan syariah .dalam rangka peningkatan jangkauan melalui kemudahan untuk membuka kantor pelayanan diharapkan dapat memberikan pengaruh pada minat masyarakat. Disisi lain secara internasional memanfaatkan investasi

Pengaruh Kurs Dolar As Dan Inflasi Terhadap Dana Pihak Ketiga (DPK) Pada Bank Nagari Syariah Cabang Batusangkar 
asing, khususnya dari timur tengah ke dalam sistim perekonomian Indonesia masih terbuka lebar. (seviana, 2014).

4. Perkembangan Dana Pihak Ketiga

Tabel 3

Data Dana pihak Ketiga periode 2013-2018

Dalam bentuk Milyar Rupiah (Rp)

\begin{tabular}{|l|l|l|l|l|l|l|}
\hline \multicolumn{1}{|c|}{ Bulan } & 2013 & 2014 & 2015 & 2016 & 2017 & 2018 \\
\hline Januari & 390 & 4.477 & 5.900 & 10.841 & 15.506 & 18.094 \\
\hline Februari & 996 & 4.862 & 5.604 & 9.910 & 15.711 & 27.122 \\
\hline Maret & 1.213 & 4.802 & 5.799 & 10.131 & 17.995 & 26.095 \\
\hline April & 1.791 & 4.625 & 6.019 & 10.480 & 18.762 & 25.845 \\
\hline Mei & 2.343 & 4.404 & 5.734 & 10.690 & 18.115 & 29.683 \\
\hline Juni & 2.550 & 4.749 & 6.093 & 10.162 & 21.819 & 27.581 \\
\hline Juli & 3.006 & 4.646 & 6.753 & 11.322 & 23.011 & 28.461 \\
\hline Agustus & 4.270 & 4.783 & 7.189 & 11.582 & 22.155 & 29.175 \\
\hline September & 4.005 & 5.198 & 7.633 & 12.784 & 24.005 & 30.535 \\
\hline Oktober & 4.166 & 5.274 & 7.756 & 13.564 & 24.800 & 35.836 \\
\hline November & 4.596 & 5.378 & 10.149 & 14.919 & 26.852 & 39.337 \\
\hline Desember & 4.108 & 6.113 & 10.878 & 17.482 & 26.853 & 34.838 \\
\hline Sumbr: ban & Nagaris Syarh & &
\end{tabular}

Sumber : bank Nagari Syariah Cabang Batusangkar (data diolah)

Dari tabel diatas dapat diketahui bahwa Dana Pihak Ketiga (DPK) mengalami kenaikan dari perode tahun 2013 sampai dengan 2018 namun fluktuatif setiap bulanya Dana Pihak Ketiga (DPK) terendah terjadi pada bulan Januari 2013 yaitu sebesar Rp 390 juta dan tertinggi terjadi pada bulan November tahun 2018 sebesar Rp 39.337 milyar jumlah kenaikanya cukup besar dalam jangka waktu 5 tahun.

Pada tahun Desember 2013 jumlah Dana Pihak Ketiga (DPK) sebesar Rp 4.108 milyar, mengalami kenaikan pada bulan Desember 2014 sebesar 6.113 milyar, kemudian pada bulan Desember 2015 mengalami kenaikan sebesar Rp 10.878 milyar, terjadi kenaikan pada bulan Desember 2016 sebesar Rp 17.482 milyar, dan tahun 2017 mengalami kenaikan lagi sebesar 26.853 milyar, pada akhir tahun 2018 mengalami kenaikan sebesar Rp. 34.838 milyar. Pertumbuhan komposisi Dana Pihak Ketiga (DPK) setiap tahunya mengalami peningkatan yang cukup stabil. Hal ini terjadi karena layanan dan sistim perbankan syariah serta minat nasabah yang ingin menabung di bank syariah semangkin meningkat.

\section{Pembahasan}

Uji Normalitas

\section{Gambar 1 \\ Hasil uji jarque-Bera test}



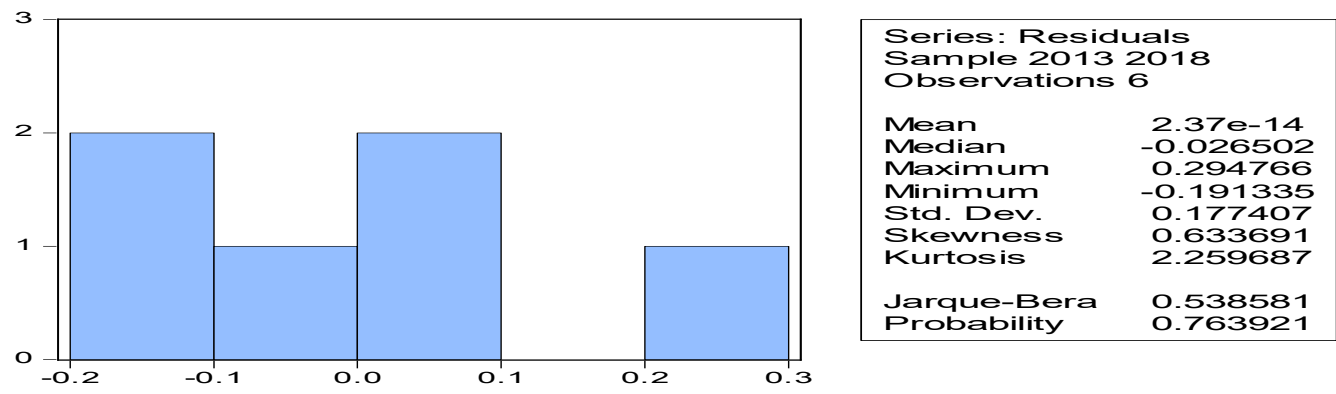

Sumber : Data Diolah

Berdasarkan grafik 4.1 di atas hasil uji normalitas menggambarkan bahwa data yang digunakan dalam penelitian ini sudah terdistribusi normal. Terlihat dari nilai probability sebesar 0.763921 lebih besar dari derajat kesalahan $\alpha=0.05(5 \%)$, sehingga model ini dikatakan telah normal dan bisa dilanjutkan kepengujian selanjutnya.

\section{Uji multikolenieritas}

Tabel 4

Hasil uji multikolenieritas

Variance Inflation Factors

Date: 06/27/19 Time: 11:18

Sample: 20132018

Included observations: 6

\begin{tabular}{cccc}
\hline \hline & $\begin{array}{c}\text { Coefficient } \\
\text { Variance }\end{array}$ & $\begin{array}{c}\text { Uncentered } \\
\text { VIF }\end{array}$ & $\begin{array}{c}\text { Centered } \\
\text { VIF }\end{array}$ \\
\hline \hline LOG(KURS) & 4.718974 & 48487.21 & 2.007314 \\
LOG(INFLASI) & 0.089450 & 24.88834 & 2.007314 \\
C & 437.1411 & 50001.35 & NA \\
\hline \hline
\end{tabular}

Sumber : Data Diolah

Berdasarkan syarat asumsi klasik regresi linear berganda dengan OLS, maka model regresi linear yang baik adalah terbebas dari adanya multikolinearitas. Dengan demikian, model yang digunakan dalam penelitian ini telah terbebas dari adanya multikolinearitas karena koefisien masingmasing dari kedua variabel indenpenden dibawah 10. Sehingga dapat dilanjutkan ke pengujian selanjutnya.

\section{Uji Autokolerasi}

\section{Tabel 5}

Hasil Autokolerasi

Breusch-Godfrey Serial Correlation LM Test: 
F-statistic

\section{Sumber : Data Diolah}

Berdasarkan table diatas dapat dilihat bahwa nilai R-squared adalah 5.973611 dan nilai probability sebesar 0.0504 yang lebih besar dari $a=0.05(5 \%)$, maka dapat disimpulkan bahwa Autokolerasi pada penelitian ini dapat dikatakan signifikan. Dan hal ini menunjukan bahwa model ini telah terbebas dari masalah autokolerasi.

\section{Uji Heteroskedastisitas}

\section{Tabel 6 \\ Hasil Uji Heteroskedasticity}

Heteroskedasticity Test: Glejser

$\begin{array}{llll}\text { F-statistic } & 0.173294 & \text { Prob. F(2,3) } & 0.8487 \\ \text { Obs*R-squared } & 0.621386 & \text { Prob. Chi-Square(2) } & 0.7329 \\ \text { Scaled explained SS } & 0.238278 & \text { Prob. Chi-Square(2) } & 0.8877 \\ \text { Sumber: Data Diolah } & & \end{array}$

Berdasarkan hasil uji heteroskedasticity test: glejser dapat diketahui bahwa nilai probability $\mathrm{F}$ adalah 0.8487 yang lebih besar dari nilai $\alpha=0.05(5 \%)$, sehingga dapat disimpulkan bahwa model ini tidak terdapat masalah heteroskedastisitas.

\section{Pengujian hipotesis}

\section{Regesi linear beganda}

Tabel 7

\section{Hasil Regresi Linear Berganda}

Dependent Variable: LOG(DPK)

Method: Least Squares

Date: 06/27/19 Time: 11:28

Sample: 20132018

Included observations: 6

\begin{tabular}{crrrr}
\hline \hline Variable & Coefficient & Std. Error & t-Statistic & Prob. \\
\hline \hline LOG(KURS) & 8.141176 & 2.172320 & 3.747688 & 0.0332 \\
LOG(INFLASI) & -0.697542 & 0.299083 & -2.332274 & 0.1019 \\
C & -52.84079 & 20.90792 & -2.527310 & 0.0856 \\
\hline \hline R-squared & 0.955204 & Mean dependent var & 23.27532 \\
Adjusted R-squared & 0.925339 & S.D. dependent var & 0.838204 \\
S.E. of regression & 0.229032 & Akaike info criterion & 0.196940 \\
Sum squared resid & 0.157367 & Schwarz criterion & 0.092820
\end{tabular}




\begin{tabular}{lllr} 
Log likelihood & 2.409180 & Hannan-Quinn criter. & -0.219862 \\
F-statistic & 31.98483 & Durbin-Watson stat & 3.068285 \\
Prob(F-statistic) & 0.009481 & & \\
\hline
\end{tabular}

Sumber : Data Diolah

Berdasarkan hasil pengolahan data pada tabel 4.7 di atas, maka didapat persamaan regresi sebagai berikut : $\operatorname{Ln} \hat{Y}=\beta 0+\beta 1 \operatorname{LnX} 1+\beta 2 \operatorname{LnX} 2=(-52.84079)$ $(8.141176)+(-0.697542)$ Berdasarkan hasil estimasi di atas dapat diketahui bahwa konstanta sebesar -52.84079 koefisien regresi LnX1 sebesar 8.141176 dan koefisien regresi LnX2 sebesar $-0.697542 \mathrm{Uji} \mathbf{T}$ tes

\section{Pengaruh dolar Amerika (Dolar AS) terhadap Dana Pihak Ketiga}

Hasil nilai dari probability (in) variabel kurs Dolar Amerika (Dolar AS) 0.0332 lebih kecil dari a= 0.05 (5\%) maka secara parsial (individu) berpengaruh signifikan terhadap variabel dependen (Dana Pihak Ketiga). Disini terbukti bahwa apabila kurs Dolar Amerika (Dolar AS) naik maka jumlah Dana Pihak Ketiga (DPK) juga akan mengalami kenaikan

\section{Pengaruh inflasi terhadap Dana Pihak Ketiga (DPK)}

Nilai probability $(\mathrm{ln})$ variabel inflasi 0.1019 lebih besar dari $a=0.05$ $(5 \%)$ maka secara parsial (individu) berpengaruh tidak signifikan terhadap variabel dependen (Dana Pihak Ketiga (DPK). Hasil penelitian ini menjelaskan bahwa inflasi berpengaruh negatif dan tidak signifikan terhadap Dana Pihak Ketiga (DPK).

\section{Uji $f$ tes}

1. Pengaruh kurs Dolar Amerika (Dolar AS) dan Inflasi secara Bersamasama terhadap Dana Pihak Ketiga (DPK)

nilai F-statistic sebesar 31.98483 dengan probability 0.009481 . Karena nilai probability lebih kecil dari derajat kesalahan $a=0.05(5 \%)$, berarti dapat disimpulkan bahwa inflasi dan kurs Dolar Amerika (Dolar AS) secara bersama-sama mempunyai pengaruh yang signifikan terhadap Dana Pihak Ketiga.

\section{Uji koefisien determinasi}

Diperoleh nilai Adjusted R2 sebesar 0.925339 (92.5339\%). Yang berarti bahwa kemampuan variabel independen (inflasi dan kurs Dana Pihak Ketiga (dpk)) dalam menjelaskan variabel dependen Dana Pihak Ketiga (dpk) adalah sebesar 0.925339 atau $92.5339 \%$ sedangkan sisanya sebesar 07.4661 (7.4661\%) dijelaskan oleh variabel lain yang tidak dibahas dalam penelitian ini.

\section{KESIMPULAN DAN KONTRIBUSI PENELITIAN}

\section{Kesimpulan}

Berdasarkan hasil penelitian yang telah penulis lakukan, maka dapat disimpulkan bahwa inflasi dan kurs US Dollar mempunyai pengaruh yang 
signifikan terhadap Dana Pihak Ketiga (DPK) bank nagari syariah cabang Batusangkar periode 2013 sampai dengan 2018, dibuktikan dengan hasil berikut :

Kurs Dolar Amerika (Dolar AS) berpengaruh positif dan signifikan terhadap Dana Pihak Ketiga (DPK), artinya saat kurs Dolar Amerika (Dolar AS) naik Dana Pihak Ketiga (DPK ) juga mengalami kenaikan. hal ini terbukti dari hasil regresi Nilai koefisien kurs Dolar Amerika (Dolar AS) sebesar 8.141176 dan nilai probability variabel Kurs Dolar Amerika (Dolar AS) 0.0332 lebih kecil dari $a=0.05(5 \%)$ maka secara parsial (individu) berpengaruh signifikan terhadap variabel dependen (Dana Pihak Ketiga).

1. Inflasi berpengaruh negatif dan tidak signifikan terhadap Dana Pihak Ketiga (DPK), artinya saat inflasi naik Dana Pihak Ketiga (DPK) mengalami penurunan. Hasil ini terbukti dari Nilai koefisien inflasi sebesar -0.697542 dan nilai probability $(\mathrm{ln})$ variabel inflasi 0.1019 lebih besar dari $\alpha=0.05(5 \%)$ maka secara parsial (individu) negatif dan tidak signifikan terhadap variabel dependen Dana Pihak Ketiga (DPK).

2. Inflasi dan Kurs Dolar Amerika (Dolar AS) secara bersama-sama mempunyai pengaruh yang signifikan terhadap komposisi Dana Pihak Ketiga (DPK). Hal ini terbukti dari hasil regresi yang mana nilai F-statistik sebesar 31.98483 dengan nilai probability 0.009481 yang lebih kecil dari $\alpha=$ $0.05(5 \%)$.

\section{Implikasi dan Saran}

Beberapa implikasi yang ditunjukan bagi Pemerintah, Bank Syariah dan peneliti berikutnya dalam menjalankan Perbankan Syariah :

1. Bagi pemerintah

Dalam hal ini sekiranya Pemerintah lebih memikirkan regulasi-regulasi tentang Dana Pihak Ketiga (DPK) di Indonesia diantaranya sebagai pengontrol, menghitung, mengawasi melihat pertumbuhan atau perkembangan Dana Pihak Ketiga (DPK) perbankan syariah agar Market share di Indonesia terus mengalami peningkatan setiap tahunnya. Dimana kita semua tahu jika Indonesia merupakan negara dengan jumlah penduduk mayoritas beragama Islam di dunia, dengan potensi tersebut pemerintah seharusnya mendukung sepenuhnya terhadap pengembangan bisnis syariah di Indonesia.

2. Bagi Bank Syariah

Dalam peningkatan Dana Pihak Ketiga (DPK) yang harus diperhatikan adalah dengan memaksimalkan dan lebih menfokuskan pada Inflasi, dan kurs. Sebab pada inflasi dan kurs ini yang berpengaruh signifikan terhadap Dana Pihak Ketiga (DPK) pada perbankan syariah.

3. Bagi Peneliti

Untuk kedepanya penelitian ini diharapakan dijadikan studi lanjutan, khususnya penelitian mengenai Dana Pihak Ketiga (DPK) perbankan syariah di Indonesia sehingga dapat memberikan hasil penelitian yang lebih akurat dan memenuhi segala kekurangan yang ada pada penelitian ini. \

\section{DAFTAR PUSTAKA}

Abimanyu,Yoopi. 2004. Memahami Kurs Valuta Asing. Fakultas Ekonomi Universitas Indonesia. Jakarta 
Adwin, S., A. Analisa Pergerakan Nilai Tukar Rupiah Terhadap Dolar Amerika Setelah Diterapkannya Kebijakan Sistem Nilai Tukar Mengambang Bebas Di Indonesia. Jurnal Akuntansi \& Keuangan . 4 [1] : 69 - 78

1999. Inflasi di indonesia : Sumber-Sumber Penyebab dan Pengendaliannya. Jurnal Akuntansi dan Keuangan 1 [1] : 54-67

Anik, S. 2008. Analisa Pengaruh Perdangangan Valuta Asing Terhadap Fluktuasi Nilai Tukar Rupiah. Jurnal JAMBSP. 5 [1] : 1 - 16

Anisa, N. 2014. Faktor-Faktor Yang Mempengaruhi Pertumbuhan Deposito Mudharabah Bank Syariah. Jurnal

Budiono. 2001. Ekonomi Moneter. BPFE Ugm. Yogyakarta 1985. Ekonomi Moneter. BPFE. Jakarta

Chapra, Muhammad Umer. 2000. Sistim Moneter Islam. Gema Insani. Jakarta

Belinda, Fatriada Indah. 2017. Pengaruh Tingkat Bagi Hasil, Kurs Dollar Dan Inflasi Terhadap Dana Pihak Ketiga (Studi Pada Bank Muamalat Indonesia (BMI) Tahun 2011-2015). Skripsi. UIN Raden Fatah. Palembang

Gampito, 2013. Ekonomi Makro Islam (Suatu Pengantar), Stain Batusangkar Press, Batusangkar

Hermawan, A., H. 2013. Norma dan Nilai dalam Ilmu Ekonomi Islam. Jurnal Media Ekonomi \& Teknologi Informasi 2 [1] : 49 -59

Huda Nurul, Dkk. 2009. Ekonomi Makro Islam; Pendekatan Teoritis. Kencana. Jakarta

Ida, M., I. 2014. Kaidah Fiqih Dalam Mengatasi Tranksaksi Yang Mengalami

Inflasi. Jurnal Economic: Jurnal Ekonomi dan Hukum Islam. 4 [1]

Idris, P. 2016. Inflasi Dalam Perspektif Islam. Jurnal LAA MAISYIR. 3 [1] : 41-58

Ikatan Bankir Indonesia. 2013. Memehami Bisnis Bank. Gramedia Pustaka Umum. Jakarta

Ikhromi, putri. 2017. Pengaruh Kurs, Suku Bunga Sertifikat Bank Indonesia, Inflasi Dan Indeks Nikkei 225 Terhadap Indeks Harga Saham Gabungan Di Bursa Efek Indonesia. Skripsi. Universitas Hasannudin. makasar

Isak Munawir, (15 Juli. 2019) Sharf Dan Permasalahannya, www.google.com/url?sa=t\&source=web\&rct=j\&url=https:/ / web.pasumber.go.id/images/gambar/02_artikel.pdf\&ved=2ahUKEwiJkJOLp7bjA hVGdCsKHZJQCU8qfjaBegQIARAB\&usg=AOvVaw2vgbGHrbRpjSQOjQx T6TTZ.

Iska, Syukri. 2012. Sistim Perbankan Syariah Di Indonesia Dalam Perspektif Fikih Ekonomi, Fajar Media Press, Yogyakarta

Ismail. 2010. Manajemen Perbankan Edisi Pertama. Kencana. Jakarta

Iqbal, Muhammad. 2015. Regresi Linear Berganda Dengan Eviews. Perbanas Institute. Jakarta

Kasmir. 2008. Pemasaran Bank cetakan ke 3. Kencana. Jakarta

2011. Dasar-Dasar Perbankancetakan Ke 9. Rajawali Press. Jakarta

Kasmuri Dkk. 2017. Buku Pedoman Penulisan Skripsi IAIN Batusangkar. IAIN Batusangkar.

Karim, Adiwarman 2010. Ekonomi Makro Islam, Rajawali Press, Jakarta

2014. Ekonomi Makro Islam. Raja Grafindo Persada. Jakarta

2013, Bank Islam Analisis Fiqih Dan Keuangan Edisi 9, Rajawali Press, Jakarta

2016. Bank Islam Analisis Fiqih Dan Keuangan. Grafindo Persada. Jakarta 
Mankiw, N. Greogory. 2000. Teori Makro Ekonomi; Teori dan kebijakan. PT. Raja Grafindo Pesrsada. Jakarta

Muchlas, Z. Agus, R., A. 2015. Faktor-faktor yang mempengaruhi kurs rupiah terhadap dolar amerika pasca krisis (2000-2010). Jurnal jibeka 9 [1] : 76- 86

Muhammad. 2015. Manajemen Dana Bank Syariah. Rajawali Press. Jakarta

Nanga, Mauna. 2005. Makro Ekonomi: Teori, Masalah, Dan Kebijkan Edisi Kedua. Raja Grafika Persada. Jakarta

Putong, Iskandar.2010. Pengantar Mikro Dan Makro. Mitra Wacana Media. Jakarta

Rahmatika. 2013. Analisis Faktor-Faktor Yang Mempengaruhi Dana Pihak Ketiga (Dpk) Pada Bank Umum Di Sulawesi Selatan Periode 1999-2012. Skripsi Universitas Hasanuddin. Makasar

Salviana. 2014. Aanalisis Pengaruh Tingkat Inflasi, Kurs Dan Nisbah Bagi Hasil

Terhadap Dana Pihak Ketiga (DPK) Perbankan Syariah Di Indonesia 2010-2013. Skripsi

UIN Syarif Hidayatullah. Jakarta

Samuelson, Paul A. 2004. Ilmu Ekonomi Makro. Media Global Edukasi. Jakarta

Sonny, H.,H. 2016. Pelemahan Rupiah : Manajemen Nilai Tukar Indonesia Dan Pelajaran Dari Masa Lalu. Jurnal Keuangan dan Perbankan 20 [2], Mei: 224240

Sugiyono. 2018. Metode Penelitian Kuatitatif, Kualitatif Dan RED. Alfabeta. Bandung

Sumitro,Wakum. 2004. Asas-Asas Perbankan Islam Dan Lembaga-Lembaga Terkait (Bamui, Takaful Dan Pasar Modal Syariah) Di Indonesia. Raja Grafindo Persada. Jakarta

Sukirno, Sandono. 2006. Makro Ekonomi : Pengantar Teori. Raja Grafindo Persada. Jakarta

2010. Makro Ekonomi : Pengantar Teori Edisi Ketiga. Rajawali Press. Jakarta

2016. Pengantar Teori Ekonomi Makro Edisi Ketiga. Rajawali Press. Jakarta

Todaro, Michel. P. 2004. Pembangunan Ekonomi 1. Edisi Kelima. Bumi Aksara. Jakarta

Tohari, Acmad. 2010. Analisis Pengaruh Nilai Tukar Rupiah Terhadap Dollar, Inflasi, Jumlah Uang Beredar (M2) Terhadap Dana Pihak Ketiga (DPK) Serta Implikasinya Pada Pembiayaan Mudharabah (Pada Perbankan Syariah Di Indonesia). Skripsi. UIN Syarif Hidayatullah. Jakarta

Triyono, 2008. Analisis Perubahan Kurs Rupiah Terhadap Dolar Amerika. Jurnal Ekonomi Pembangunan 9 [12] : 156-167

Wijaya, Tony. 2013. Metodologi Penelitian Ekonomi Dan Bisnis-Toeri Pengantar Dan Praktik. Graha Ilmu. Yogyakarta

Wiranta, V Sujarweni. 2015. Spss Untuk Penelitian. Pustaka Baru Press. Yoyakarta

Yustha, Muthaharsyah. 2017. Pengaruh Inflasi Dan Kurs US Dollar Terhadap Komposisi Tabungan Mudharabah Perbankan Syariah Di Indonesia. Skripsi. IAIN Batusangkar

Zulkifli, Sunarto. 2003. Panduan Praktis Transaksi Perbankan Syariah. Ekonisia. Yogyakarta. 